\title{
MENGUKUR TINGKAT KEPUASAN MASYARAKAT \\ PADA PENGGUNA LAYANAN PERIZINAN USAHA DI KABUPATEN CIREBON TAHUN 2016
}

\author{
Syaeful Bakhri \\ Jurusan Hukum Ekonomi Islam Fakultas Syari’ah dan Ekonomi Islam \\ Institut Agama Islam Negeri Syekh Nurjati Cirebon \\ email: sultan01aulia@yahoo.com
}

\begin{abstract}
The importance of improving the quality of service to the community is a thing that can not be delayed, because with good service quality, it will be able to impact on increasing the amount of incoming investment. Public service is any service activities undertaken for the implementation of public services as an effort to meet the needs of the public and the implementation of the provisions of legislation. For the result of Community Satisfaction Index Survey on service quality of Integrated Licensing Service of Cirebon Regency Year 2016 which has the highest value is service ability of officer in giving service and service of suitability of service requirement with service type respectively 85,42, while having the lowest value is Fairness service cost to get service and suitability between cost incurred with cost which have been determined which each value equal to 77,75.
\end{abstract}

Keywords: Satisfaction, Public Service, Quality of Human Resources, Procedures.

\begin{abstract}
Abstrak
Pentingnya peningkatan kualitas pelayanan kepada masyarakat adalah hal yang tidak dapat ditunda, karena dengan kualitas pelayanan yang baik, akan berdampak pada peningkatan jumlah investasi yang masuk. Pelayanan publik adalah kegiatan pelayanan yang dilakukan untuk pelaksanaan pelayanan publik sebagai upaya memenuhi kebutuhan masyarakat dan pelaksanaan ketentuan perundang-undangan. Untuk hasil Survei Indeks Kepuasan Masyarakat terhadap kualitas pelayanan Pelayanan Perizinan Terpadu Kabupaten Cirebon Tahun 2016 yang memiliki nilai tertinggi adalah kemampuan pelayanan petugas dalam memberikan pelayanan dan pelayanan kesesuaian kebutuhan layanan dengan jenis layanan masing-masing sebesar 85,42, sementara memiliki Nilai terendah adalah biaya layanan Fairness untuk mendapatkan pelayanan dan kesesuaian antara biaya yang dikeluarkan dengan biaya yang telah ditentukan dimana masing-masing nilai sebesar 77,75.
\end{abstract}

Kata Kunci: Kepuasan, Pelayanan Publik, Kualitas Sumber Daya Manusia, Prosedur. 


\section{PENDAHULUAN}

Penyelenggaraan pelayanan publik yang dilaksanakan oleh aparatur pemerintah dalam berbagai sektor pelayanan, terutama yang menyangkut pelayanan publik dan kebutuhan dasar mayarakat, kinerjanya harus selalu ditingkatkan. Masih adanya pengaduan atau keluhan masyarakat dan dunia usaha, menyangkut prosedur perizinan, transparansi, kurangnya informasi, konsisten dalam pengurusan perizinan, serta fasilitas yang terbatas, permasalahan sarana dan prasarana, suasana lingkungan, persoalan waktu dan biaya tentunya menjadi Triger bagi badan pelayanan publik di Kabupaten Cirebon untuk selalu berbenah dan memperbaiki diri.

Oleh karena itu pelayanan publik harus mendapat perhatian dan penanganan yang sungguh-sungguh oleh semua aparatur, karena merupakan tugas dan fungsi yang melekat pada setiap aparatur sebagai jajaran terdepan instansi pemberi pelayanan publik (public service).

Tingkat kualitas kinerja pelayanan publik memiliki dampak (impact) yang luas dalam berbagai kehidupan, terutama untuk mencapai tingkat kesejahteraan masyarakat. Oleh karena itu upaya penyempurnaan pelayanan publik (public service) harus dilakukan secara terus menerus dan berkesinambungan. Baik tidaknya kualitas layanan bukanlah berdasarkan sudut pandang atau persepsi penyedia jasa/layanan melainkan berdasarkan pada persepsi konsumen. Seperti yang dikemukakan Kotler dalam Wisnalmawati bahwa kualitas harus dimulai dari kebutuhan pelanggan dan berakhir pada persepsi pelanggan. ${ }^{1}$

Upaya peningkatan kualitas pelayanan harus dilaksanakan secara bersama-sama, terpadu, terprogram, terarah dan konsisten dengan memperhatikan kebutuhan dan harapan masyarakat, sehingga

\footnotetext{
${ }^{1}$ Wisnalmawati, "Pengaruh Persepsi Dimensi Kualitas Layanan Terhadap Niat Pembelian Ulang", Jurnal Ekonomi \& Bisnis, Jilid 10, No. 03 (Juni, 2005): 153-165.
}

pelayanan yang diberikan kepada masyarakat dapat diberikan secara cepat, murah, terbuka, sederhana dan mudah dilaksanakan serta tidak diskriminatif.

Dalam pelayanan publik, kepuasan pelayanan merupakan fungsi dan kinerja. Oliver dalam Tjiptono mengemukakan bahwa kepuasan secara keseluruhan ditentukan oleh ketidaksesuain antara harapan dengan layanan yang diterima pelanggan. $^{2}$

Menurut Oka A Yoeti, kepuasan pelanggan banyak ditentukan oleh kualitas performa dalam pelayanan di lapangan. Apabila pelayanan tidak sama atau tidak sesuai dengan harapan pelanggan maka dimata pelanggan pelayanan yang diberikan dinilai jelek dan tidak memuaskan. Pemerintah merupakan suatu entitas yang memiliki fungsi dan tujuan memberikan layanan publik kepada kelompok masyarakat dengan menjalankan peran sebagai organisasi publik non profit. Pelayanan publik didasarkan atas fungsi, peran, kewajiban dan tujuan dalam pemenuhan kebutuhan masyarakat akan barang dan jasa yang memiliki karakteristik sebagai barang publik. ${ }^{3}$

Ekspektasi masyarakat yang besar dapat merubah paradigma dan tatanan fundamental pada sistem Pemerintahan Daerah. Perubahan sistem pemerintahan di daerah berbalik haluan dari sentralisasi menjadi desentralisasi dengan pelimpahan sebagian besar urusan pemerintahan kepada daerah. Pelimpahan penyelenggaraan urusan tersebut disertai dengan desentralisasi fiscal untuk membiayai penyelenggaraan urusan pemerintahan yang dilimpahkan kepada daerah. Perubahan tatanan fundamental sistem pemerintahan di daerah dari sentralisasi menjadi desentralisasi diawali dengan Undang-Undang Nomor 22 Tahun 1999 tentang Pemerintahan Daerah yang

${ }^{2}$ Fandy Tjiptono, Manajemen Jasa, Edisi Pertama (Yogyakarta: Andi Offset), 146.

${ }^{3}$ Oka A Yoeti, Customer Service Cara Efektif Memuaskan Pelanggan (Jakarta: Prandya Paramita, 2003), 36. 
kemudian diperbaharui dengan lahirnya Undang-Undang Nomor 32 Tahun 2004 yang memiliki filosofi untuk memberikan pemerataan pelayanan publik dan untuk lebih mendekatkan serta meningkatkan aksesibilitas masyarakat terhadap pelayanan publik melalui pelimpahan penyelenggaraan sebagian urusan kepada Pemerintah Daerah. Pemberian pelayanan publik oleh aparatur pemerintah kepada masyarakat merupakan implikasi dari fungsi aparat negara sebagai pelayan masyarakat sehingga kedudukan aparatur pemerintah dalam pelayanan umum (public services) sangat strategis karena akan menentukan sejauhmana pemerintah mampu memberikan pelayanan yang sebaikbaiknya bagi masyarakat dan sejauhmana negara telah menjalankan perannya dengan baik sesuai dengan tujuan pendiriannya. Menurut Achmad Nurmandi salah satu peran utama pemerintahan, termasuk pemerintahan daerah di masa sekarang adalah bagaimana kemampuan daerah mampu memberikan solusi terhadap masalah public dan mampu mengartikulasikan dan merealisasikan kepentingan dan pelayanan publik. Secara harafiah kepentingan publik berarti kepentingan umum, yang mencerminkan kepentingan komponen atau kelompok yang ada dalam suatu masyarakat. ${ }^{4}$

Berkenaan dengan kebijakan pemberian layanan publik yang baik dan berkualitas, Amri Marzali menjelaskan bahwa kebijakan atau policy berkaitan dengan perencanaan, pengambilan dan perumusan keputusan dan evaluasi terhadap dampak dari pelaksanaan tersebut terhadap orang banyak yang menjadi sasaran kebijakan. ${ }^{5}$

\section{METODE PENELITIAN}

\section{Jenis Penelitian dan Pengumpulan Data}

Jenis penelitian yang digunakan dalam melakukan kajian ini menggunakan metode Deskriptif. Penelitian deskriptif menurut

${ }^{4}$ Achmad Nurmandi, Manajemen Pelayanan Publik Lampiran UU No. 25 tahun 2009 tentang Pelayanan Publik (Jakatra: Sinergi Visi Utama, 2009), 19.

${ }^{5}$ Amri Marzali, Antropologi dan Kebijakan Publik (Jakarta: Kencana Prenada Media Group, 2012), 19-20.
Deni Darmawan adalah penelitian yang berusaha menuturkan pemecahan masalah yang ada sekarang berdasarkan data data yang kemudian di analisis dan diinterpretasi. Pada bagian lain dijelaskan lebih lanjut bahwa metode deskriptif adalah metode penelitian yang digunakan untuk meneliti di lapangan hal hal yang sedang terjadi. ${ }^{6}$

Pengumpulan data dilakukan dengan melakukan survey (Field Studies) yaitu salah satu metode penelitian kuantitatif yang sering digunakan pada penelitian tentang bagaimana mengukur tingkat kepuasan masyarakat pengguna pelayanan. Kuesioner yang disiapkan pada penelitian ini mengacu pada Peraturan Menteri Aparatur Negara dan Reformasi Birokrasi Nomor 16 tahun 2014 tentang pedoman survey kepuasan masyarakat terhadap penyelenggaran pelayanan publik.

Menurut Indrawan dan Yaniawati jenis survey yang mengamati sebuah objek penelitian baik satu maupun beberapa variabel dengan cara menghimpun data pada suatu masa yang sama. Kelebihan survey ini dengan survey lainya adalah pelaksanaanya yang lebih sederhana, lebih efisien dan kemungkinan lebih efektif karena dapat lebih cepat diketahui hasilnya. ${ }^{7}$

Definisi berbeda disampaikan oleh Yanuar Ikbar bahwa penelitian survey adalah merupakan penelitian yang dilakukan pada populasi besar maupun kecil, tetapi data yang dipelajari adalah data dari sample yang diambil dari populasi tersebut, sehingga ditemukan kejadian-kejadian relative, distribusi hubungan -hubungan antar variable, sosiologis maupun psikologis. $^{8}$

${ }^{6}$ Deni Darmawan, Metode Penelitian Kuantitatif (Bandung: Remaja Rosdakarya, 2013), 37 dan 75.

${ }^{7}$ Rully Indrawan dan Poppy Yaniawati, Metode Penelitian Kuantitatif, Kualitatif, dan campuran untuk Manajemen. Pembangunan dan Pendidikan (Bandung: Refika Aditama, 2014), 5455.

${ }^{8}$ Yanuar Ikbar, Metode Penelitian Sosial Kualitatif Panduan Membuat Tugas Akhir/Karya Ilmiah (Bandung: Refika Aditama, 2012), 182. 


\section{Populasi dan Teknik Pengambilan Sampling}

Menurut Deni Darmawan populasi adalah sumber data dalam penelitian tertentu yang memiliki jumlah banyak dan luas. Jika data yang diambil dari semua populasi maka akan memerlukan dana dan waktu yang tidak sedikit. $^{9}$

Adapun populasi pada penelitian ini adalah seluruh masyarakat yang melakukan pengurus perizinan usaha di Wilayah Kabupaten Cirebon pada Januari hingga Desember tahun 2016. Adapun pelayanan perijinan usaha dalam penelitian ini meliputi pengurusan Tanda Daftar Perusahaan (TDP), Surat Ijin Usaha Perdagangan (SIUP), Surat ijin Gangguan (HO) dan Ijin Mendirikan Pembangunan (IMB).

Berikut ini adalah populasi dari masyarakat yang mengurus perizinan usaha di Kabupaten Cirebon periode Januari sampai dengan Desember 2016.

Tabel 1: Populasi masyarakat yang melakukan pengurusan perizinan usahan tahun 2016

\begin{tabular}{clc}
\hline No & Bulan & Jumlah \\
\hline 1 & Januari & 43 \\
2 & Februari & 38 \\
3 & Maret & 73 \\
4 & April & 79 \\
5 & Mei & 74 \\
6 & Juni & 80 \\
7 & Juli & 80 \\
8 & Agustus & 81 \\
9 & September & 77 \\
10 & Oktober & 83 \\
11 & November & 75 \\
12 & Desember & 76 \\
\hline \multicolumn{2}{c}{ Jumlah }
\end{tabular}

Secara umum, menurut Deni Darmawan ada dua jenis teknik pengambilan sampel yaitu, sampel acak atau

${ }^{9}$ Deni Darmawan, Metode Penelitian Kuantitatif (Bandung: Remaja Rosdakarya, 2013), 139. random sampling/Probability Sampling, dan sampel tidak acak atau nonrandom sampling/nonprobability Sampling. ${ }^{10}$

Sampel yang digunakan dalam penelitian ini menggunakan random sampling, dimana sampel yang diambil dalam penelitian ini dilakukan secara acak . Dalam metode ini memungkinkan pada semua populasi diberikan kesempatan yang sama menjadi sampel. Dengan kata lain tanpa pandang bulu semua subjek penelitian memiliki peluang yang sama. ${ }^{11}$

Dalam random sampling karena elemen penelitian memiliki kemungkinan yang sama untuk dijadikan sampel, misalnya jumlah populasi 100 dan sampel yang diambil adalah 20 maka mempunyai kemungkinan 20/100. Dalam penelitian ini sampel yang diambil adalah 300/859. Sampel setara dengan 35\% dari jumlah jumlah populasi. Untuk mengantisipasi biaya yang dikeluarkan maka wawancara dengan responden dilakukan di Kantor Badan Pelayanan Perijinan Terpadu (BPPT) pada saat responden melakukan pengurusan perizinan.

\section{Metode Analisis}

Nilal Indeks kepuasan dihitung dengan menggunakan "nilai rata-rata tertimbang" masing-masing unsur variabel. Dalam penghitungan indeks kepuasan terhadap pelayanan yang diberikan akan dikaji dari setiap unsur layanan memiliki penimbang yang sama dengan rumus sebagai berikut;

Bobot nilai rata-rata tertimbang

$$
=\frac{\text { Jumlah Bobot }}{\text { Jumlah Unsur }}
$$

Untuk memperoleh nilai IKK digunakan pendekatan nilai rata-rata tertimbang dengan rumus sebagai berikut:

$$
\mathbf{I K M}=\frac{\text { Total dari nilai persepsi pada layanan }}{\text { Total layanan yang Terisi }} \mathrm{X}
$$

${ }^{10}$ Deni Darmawan, Metode Penelitian Kuantitatif (Bandung: Remaja Rosdakarya, 2013), 145 .

${ }^{11}$ Suharsimi Arikunto, Manajemen Penelitian (Jakarta: Rineka Cipta 2007), 95. 
Untuk memudahkan interpretasi terhadap penilaian IKM yaitu antara 25-100 maka hasil penilaian tersebut diatas dikonversikan dengan nilai dasar 25, dengan rumus sebagai berikut:

Index Kepuasan Masyarakat X 25

Mengingat unit pelayanan mempunyai karakteristik yang berbedabeda, maka setiap layanan dimungkinkan untuk (1) Menambah unsur yang dianggap relevan, (2) Memberikan bobot yang berbeda terhadap unsur yang dominan dalam unit layanan, dengan catatan jumlah bobot seluruh unsur tetap.

DISTRIBUSI FREKUENSI KINERJA DAN KEPENTINGAN MASYARAKAT UNTUK TIAP-TIAP UNSUR DIMENSI KUALITAS PELAYANAN

Kemudahan prosedur pelayanan perizinan usaha

Tabel 3 : Kemudahan Prosedur Pelayanan perizinan usaha di BPPT Kabupaten Cirebon Tahun 2016

\begin{tabular}{lcc}
\hline \multicolumn{3}{c}{ Kinerja } \\
\hline Keterangan & Frekuensi & Presentasi \\
\hline Tidak mudah & 1 & .3 \\
Kurang & 7 & 2.3 \\
mudah & 161 & 53.7 \\
Mudah & 131 & 43.7 \\
Sangat mudah & $\mathbf{3 0 0}$ & $\mathbf{1 0 0 . 0}$ \\
\hline \multicolumn{2}{c}{ Total }
\end{tabular}

Berdasarkan tabel 3 dari 300 responden, didapatkan penilaian masyarakat terhadap kinerja kemudahan prosedur pelayanan perizinan usaha sebagian besar masyarakat menyatakan mudah yaitu sebanyak $161 \quad(53,7 \%)$ responden dan menyatakan sangat mudah terdapat sebanyak $131(43,7 \%)$. responden dan menyatakan kurang mudah terdapat sebanyak $7(2,3 \%)$.

Untuk variabel unsur kemudahan prosedur pelayanan perizinan usaha di BPPT Kabupaten Cirebon, masih harus diperbaiki dan ditingkatkan, karena masih ditemukan masyarakat menyatakan kurang dan tidak mudah dalam memperoleh prosedur pelayanan perizinan usaha.

Kesesuaian persyaratan perizinan dengan jenis pelayanan perizinan usaha

Tabel 4 : Kesesuaian persyaratan perizinan dengan jenis pelayanan perizinan usaha di BPPT Kabupaten Cirebon Tahun 2016

\begin{tabular}{|c|c|c|}
\hline \multicolumn{3}{|c|}{ Kinerja } \\
\hline Keterangan & Frekuensi & Presentasi \\
\hline Tidak sesuai & - & \\
\hline $\begin{array}{l}\text { Kurang } \\
\text { sesuai }\end{array}$ & 2 & .7 \\
\hline Sesuai & 171 & 57.0 \\
\hline Sangat sesuai & 127 & 42.3 \\
\hline Total & 300 & 100.0 \\
\hline
\end{tabular}

Sumber : Hasil Survey, 2016

Berdasarkan tabel 4 dari 300 responden, didapatkan penilaian masyarakat terhadap kinerja kesesuaian persyaratan perizinan dengan jenis pelayanan perizinan usaha sebagian besar masyarakat menyatakan sesuai yaitu sebanyak 171 $(57,0 \%)$ responden dan sangat sesuai terdapat $127(42,3 \%)$.

Kejelasan informasi mengenai jenis dan prosedur pelayanan yang diberikan petugas

Tabel 5: Kejelasan informasi mengenai jenis dan prosedur pelayanan di BPPT Kabupaten Cirebon Tahun 2016

\begin{tabular}{lcc}
\hline & Kinerja & \\
\hline \multicolumn{1}{c}{ Keterangan } & Frekuensi & Presentasi \\
\hline Tidak jelas & - & - \\
Kurang jelas & 34 & 11.3 \\
Jelas & 138 & 46.0 \\
Sangat jelas & 128 & 42.7 \\
\hline \multicolumn{1}{c}{ Total } & $\mathbf{3 0 0}$ & $\mathbf{1 0 0 . 0}$ \\
\hline
\end{tabular}

Sumber: Hasil Survey, 2016

Berdasarkan tabel 5 dari 300 responden, didapatkan penilaian masyarakat terhadap kinerja kejelasan informasi mengenai jenis dan prosedur pelayanan sebagian besar masyarakat menyatakan jelas 
yaitu sebanyak $138(46,0 \%)$ responden dan yang menyatakan sangat jelas jelas sebanyak $128(42,7 \%)$ dan responden dan yang menyatakan kurang jelas sebanyak 34 $(11,3 \%)$. Kejelasan informasi mengenai jenis dan prosedur pelayanan di BPPT Kabupaten Cirebon, sebaiknya selalu disosialisasikan kepada masyarakat, sehingga masyarakat memperoleh informasi yang jelas, yang diharapkan dapat memudahkan masyarakat dalam memperoleh layanan perizinan di BPPT.

\section{Kemampuan atau kompetensi petugas dalam memberikan pelayanan perizinan usaha}

Tabel 6: Kemampuan atau kompetensi petugas di BPPT Kabupaten Cirebon Tahun 2016

\begin{tabular}{lcc}
\hline \multicolumn{3}{c}{ Kinerja } \\
\hline \multicolumn{1}{c}{ Keterangan } & Frekuensi & Presentasi \\
\hline Tidak mampu & - & - \\
$\begin{array}{l}\text { Kurang } \\
\text { mampu }\end{array}$ & 6 & 2.0 \\
$\begin{array}{l}\text { Mampu } \\
\text { Sangat } \\
\text { mampu }\end{array}$ & 163 & 54.3 \\
\hline \multicolumn{1}{c}{ Total } & 131 & 43.7 \\
\hline
\end{tabular}

Sumber: Hasil Survey, 2016

Berdasarkan tabel 6 dari 300 responden, didapatkan penilaian masyarakat terhadap kinerja kemampuan atau kompetensi petugas dalam memberikan pelayanan perizinan usaha sebagian besar masyarakat menyatakan mampu yaitu sebanyak $163(54,3 \%)$ responden dan yang menyatakan sangat mampu sebanyak 131 $(43,7 \%)$ dan responden dan yang menyatakan kurang mampu sebanyak 6 $(2,0 \%)$ responden.Perlu adanya peningkatan kompetensi atau kemampuan SDM petugas BPPT baik secara formal dan informal sehingga dapat meningkatkan kompetensi petugas di BPPT Kabupaten Cirebon terhadap layanan publik.

Kompetensi karyawan sangat erat hubungannya dengan disiplin individu dengan system administrasi publik dimana dia bekerja, terutama dalam membentuk budaya kerja yang baik. Maka indeks kepuasan masyarakat menyangkut kompetensi karywan sangat penting di evalusai, seperti yang dikatakan Dwiputrianti dan Sanusi bahwa kebijakan kepegawaian sebagai salah satu dasr landasan hukum untuk menerapkan konsep pengembangan SDM di sector public yang berorientasi pada peningkatan mutu human capital. $^{12}$

\section{Ketepatan pelaksanaan terhadap jadwal waktu pelayanan perizinan usaha}

Tabel 7: Ketepatan pelaksanaan terhadap jadwal di BPPT Kabupaten Cirebon Tahun 2016

\begin{tabular}{lcc}
\hline \multicolumn{3}{c}{ Kinerja } \\
\hline Keterangan & Frekuensi & Presentasi \\
\hline Tidak tepat & 2 & 0.7 \\
Kurang tepat & 27 & 9.0 \\
Tepat & 148 & 49.3 \\
Sangat tepat & 123 & 41.0 \\
\hline \multicolumn{1}{c}{ Total } & $\mathbf{3 0 0}$ & $\mathbf{1 0 0 . 0}$ \\
\hline Sumber: Hasil Survey, 2016 &
\end{tabular}

Berdasarkan tabel 7 dari 300 responden, didapatkan penilaian masyarakat terhadap kinerja ketepatan pelaksanaan jadwal waktu pelayanan perijijanan sebagian besar masyarakat menyatakan tepat yaitu sebanyak $148 \quad(49,8 \%)$ responden, yang menyatakan sangat tepat sebanyak $123(41,0 \%)$ responden, dan yang menyatakan kurang tepat sebanyak 27 $(9,0 \%)$ responden. Ketepatan pelaksanaan terhadap jadwal waktu pelayanan perizinan usaha biasanya sangat mempengaruhi terhadap kepuasan masyarakat, semakin tidak tepat jadwal pelayanan perizinan usaha yang telah BPPT tetapkan, maka masyarakat semakin merasa tidak puas.

${ }^{12}$ Septiana Dwiputrianti dan Anwar Sanusi, Evaluasi Kebijakan dalam Upaya Peningkatan Mutu Human Capital di Sektor Publik (Comparative Study dengan Australia) dalam Pengembangan Human Capital, Perspektif Nsional, regional dan Global (Graha Ilmu, Yogyakarta), 103. 
Kesopanan dan keramahan petugas dalam memberikan pelayanan perizinan usaha

Tabel 8: Kesopanan dan keramahan petugas dalam memberikan pelayanan perizinan usaha di BPPT Kabupaten Cirebon Tahun 2016

\begin{tabular}{lcc}
\hline & Kinerja & \\
Keterangan & Frekuensi & Presentasi \\
\hline Tidak sopan & - & - \\
Kurang sopan & 4 & 1.3 \\
Sopan & 172 & 53.3 \\
Sangat sopan & 124 & 41.3 \\
\hline \multicolumn{1}{c}{ Total } & $\mathbf{3 0 0}$ & $\mathbf{1 0 0 . 0}$ \\
\hline
\end{tabular}

Sumber: Hasil Survey, 2016

Berdasarkan tabel 8 dari 300 responden, didapatkan penilaian masyarakat terhadap kinerja kesopanan dan keramahan petugas sebagian besar masyarakat menyatakan sopan yaitu sebanyak 172 $(53,3 \%)$ responden, yang menyatakan sangat sopan $124(42,3 \%)$ responden dan yang menyatakan kurang sopan sebanyak 4 (1.3\%) responden.

Dalam memerikan pelayanan harus diperhatikan juga bagaimana kita bisa berlaku sopan kepada masyarakat, sehingga masyarakat merasa nyaman dan puas terhadap pelayanan yang kita berikan.

\section{Keadilan untuk mendapatkan pelayanan perizinan usaha}

Tabel 9: Keadilan untuk mendapatkan pelayanan perizinan usaha di BPPT Kabupaten Cirebon Tahun 2016

\begin{tabular}{lcc}
\hline \multicolumn{3}{c}{ Kinerja } \\
\hline Keterangan & Frekuensi & Presentasi \\
\hline Tidak adil & - & - \\
Kurang adil & 7 & 2.3 \\
Adil & 232 & 77.3 \\
Sangat adil & 61 & 20.3 \\
\hline \multicolumn{1}{c}{ Total } & $\mathbf{3 0 0}$ & $\mathbf{1 0 0 . 0}$ \\
\hline
\end{tabular}

Sumber: Hasil Survey, 2016

Berdasarkan tabel 9 dari 300 responden, didapatkan penilaian masyarakat terhadap kinerja keadilan dalam mendapatkan pelayanan perizinan usaha sebagian besar masyarakat menyatakan adil yaitu sebanyak $232(77,3 \%)$, yang menyatakan sangat adil $61 \quad(20,3 \%)$ responden dan yang menyatakan kurang adil terdapat 7 responden $(2.3 \%)$.

\section{Kewajaran biaya untuk mendapatkan pelayanan perizinan usaha}

Tabel 10: Kewajaran biaya untuk mendapatkan pelayanan perizinan usaha di BPPT Kabupaten Cirebon Tahun 2016

\begin{tabular}{lcc}
\hline \multicolumn{3}{c}{ Kinerja } \\
\hline \multicolumn{1}{c}{ Keterangan } & Frekuensi & Presentasi \\
\hline Tidak wajar & - & - \\
Kurang wajar & 30 & 10.0 \\
Wajar & 207 & 69.0 \\
Sangat wajar & 63 & 21.0 \\
\hline \multicolumn{1}{c}{ Total } & $\mathbf{3 0 0}$ & $\mathbf{1 0 0 . 0}$ \\
\hline
\end{tabular}

Sumber: Hasil Survey, 2016

Berdasarkan tabel 10 dari 300 responden, didapatkan penilaian masyarakat terhadap kinerja kewajaran biaya untuk pelayanan perijijnan sebagian besar masyarakat menyatakan wajar yaitu sebanyak $207 \quad(69,0 \%)$ responden yang menyatakan sangat wajar $63(21 \%)$ dan yang menyatakan kurang wajar sebanyak 30 $(10.0 \%)$ responden . Walaupun hanya sebagian kecil yang menyatakan kurang wajar tetap harus mendapatkan perhatian dan perlunya sosialisasi besaran biaya perizinan usaha yang telah ditetapkan oleh Pemerintah Kabupaten Cirebon.

\begin{tabular}{lcc}
$\begin{array}{l}\text { Kesesuaian } \\
\text { dikeluarkan } \\
\text { ditetapkan } \\
\text { Tabel 11: Kesesuaian antara biaya yang dikeluarkan } \\
\text { dengan biaya yang telah ditetapkan di BPPT } \\
\text { Kabupaten Cirebon Tahun 2016 }\end{array}$ \\
\begin{tabular}{ccc}
\multicolumn{3}{c}{ Kinerja } \\
\hline \multicolumn{3}{c}{ biaya } \\
yang
\end{tabular} \\
\hline Keterangan & Frekuensi & Presentasi \\
\hline Tidak sesuai & 1 & 0.3 \\
Kurang sesuai & 28 & 9.3 \\
Sesuai & 208 & 69.3 \\
Sangat sesuai & 63 & 21.0 \\
\hline \multicolumn{1}{c}{ Total } & $\mathbf{3 0 0}$ & $\mathbf{1 0 0 . 0}$ \\
\hline Sumber: Hasil Survey, 2016 &
\end{tabular}


Berdasarkan tabel 11 dari 300 responden, didapatkan penilaian masyarakat terhadap kinerja kesesuaian biaya yang dikeluarkan dengan biaya yang telah ditentukan sebagian besar masyarakat menyatakan sesuai yaitu sebanyak 208 $(69,3 \%)$ responden dan yang menyatakan kurang sesuai sebanyak $28 \quad(9,3 \%)$ responden. Sebaiknya perlu adanya pengkajian ulang terhadap kesesuaian antara biaya yang dikeluarkan masyarakat dengan biaya yang telah ditetapkan pemerintah, sehingga masyarakat merasa wajar/sesuai antara pelayanan yang diperoleh dan biaya yang harus dikeluarkan.

Kenyamanan di lingkungan unit pelayanan perizinan usaha

Tabel 12: Kenyamanan di lingkungan unit pelayanan perizinan usaha di BPPT Kabupaten Cirebon Tahun 2016

\begin{tabular}{lcc}
\hline \multicolumn{3}{c}{ Kinerja } \\
\hline Keterangan & $\begin{array}{c}\text { Frekuens } \\
\text { i }\end{array}$ & Presentasi \\
\hline Tidak nyaman & - & - \\
Kurang nyaman & 5 & 1.7 \\
Nyaman & 233 & 77.7 \\
Sangat nyaman & 62 & 20.7 \\
\hline \multicolumn{1}{c}{ Total } & $\mathbf{3 0}$ & $\mathbf{1 0 . 0}$ \\
\hline
\end{tabular}

Sumber: Hasil Survey, 2016

Berdasarkan tabel 12 dari 300 responden, didapatkan penilaian masyarakat terhadap kinerja kenyamanan lingkungan sebagian besar masyarakat menyatakan sangat nyaman yaitu sebanyak 233 (77,7\%) responden dan menyatakan kurang nyaman sebanyak $5(1,7 \%)$ responden.
Keamanan di lingkungan unit pelayanan perizinan usaha

Tabel 13: Keamanan di lingkungan unit pelayanan perizinan usaha di BPPT Kabupaten Cirebon Tahun 2016

\begin{tabular}{lcc}
\hline & Kinerja & \\
\hline Keterangan & Frekuensi & Presentasi \\
\hline Tidak aman & - & - \\
Kurang aman & 7 & 2.3 \\
Aman & 239 & 79.7 \\
Sangat aman & 54 & 18.0 \\
\hline \multicolumn{1}{c}{ Total } & $\mathbf{3 0 0}$ & $\mathbf{1 0 0 . 0}$ \\
\hline Sumber: Hasil Survey, 2016 &
\end{tabular}

Berdasarkan tabel 13 dari 300 responden, didapatkan penilaian masyarakat terhadap kinerja keamanan lingkungan sebagian besar masyarakat menyatakan aman yaitu sebanyak $239 \quad(79,7 \%)$ responden dan yang menyatakan kurang $\begin{array}{llll}\text { aman } & \text { sebanyak } 7 \text { (2.3\%). Faktor }\end{array}$ Kenyamanan dan keamanan dalam pelayanan publik sudah relative baik.

NILAI PERSEPSI, INTERVAL IKM, INTERVAL KONVERSI IKK, MUTU LAYANAN DAN KINERJA LAYANAN BADAN PELAYANAN PERIZINAN USAHA TERPADU KAB. CIREBON

Tabel 14: Nilai Persepsi, Interval IKM, Interval Konversi IKK, Mutu dan Kinerja Layanan

\begin{tabular}{ccccc}
\hline \multicolumn{5}{c}{ Kepuasan Masyarakat } \\
\hline $\begin{array}{c}\text { Nilai } \\
\text { Persepsi }\end{array}$ & $\begin{array}{c}\text { Nilai } \\
\text { Interval } \\
\text { IKM }\end{array}$ & $\begin{array}{c}\text { Nilai } \\
\text { interval } \\
\text { konversi } \\
\text { IKM }\end{array}$ & $\begin{array}{c}\text { Mutu } \\
\text { Pelayanan }\end{array}$ & Keterangan \\
\hline 3 & $2,51-$ & 81,02 & B & Baik \\
\hline
\end{tabular}

Sumber: Hasil perhitungan, 2016

Berdasarkan tabel 14 pada nilai persepsi, interval IKM, interval konversi IKK, mutu layanan dan kinerja layanan, didapatkan nilai interval konversi IKM yaitu 81,02 artinya mutu pelayanan mempunyai nilai B, yaitu baik. Dengan interprestasi bahwa mutu pelayanan yang telah diberikan oleh Badan Pelayanan perizinan usaha Terpadu Kabupaten Cirebon untuk periode Januari sampai Desember 2016, masyarakat 
menyatakan baik terhadap pelayanan yang telah diberikan.

\section{KESIMPULAN}

Setelah melalui analisis dan pembahasan pada survey indeks kepuasan masyarakat pada layanan perizinan usaha di Kabupaten Cirebon tahun 2016, dapat disimpulkan sebagai berikut pertama, hasil survey Indeks Kepuasan Masyarakat terhadap mutu layanan Badan Pelayanan Perizinan Terpadu Kabupaten Cirebon Tahun 2016 adalah 81,02 , berarti ada kenaikan $0,52 \%$ dari Indeks Kepuasan Masyarakat Tahun 2015 sebesar 80,5.

Dan kedua, mutu pelayanan hasil survey Indeks Kepuasan Masyarakat tahun 2016 untuk masing-masing adalah sebagai berikut: 1) Kemudahan prosedur pelayanan perizinan sebesar 85,17; 2) Kesesuaian persyarataan perizinan dengan jenis pelayanan sebesar 85,42; 3) Kejelasan informasi mengenai jenis dan prosedur pelayanan sebesar 82,83 ; 4) Kemampuan atau kompetensi petugas dalam memberikan pelayanan sebesar 85,42; 5) Ketepatan pelaksanaan terhadap jadwal waktu pelayanan sebesar 82,67 ; 6)Kesopanan dan keramahan petugas dalam memberikan pelayanan sebesar 85,00 ; 7) Keadilan untuk mendapatkan pelayanan sebesar 79,$50 ; 8$ ) Kewajaran biaya untuk mendapatkan pelayanan sebesar 77,75 ; 9) Kesesuaian antara biaya yang dikeluarkan dengan biaya yang telah ditetapkan sebesar 77,7rkan dengan biaya yang telah ditetapkan sebesar 77,75 ; 10) Kenyamanan dilingkungan unit pelayanan sebesar 79,5; dan 11) Keamanan dilingkungan unit pelayanan sebesar 78,92. Untuk hasil Survey Indeks Kepuasan Masyarakat terhadap mutu layanan Badan Pelayanan Perizinan Terpadu Kabupaten Cirebon Tahun 2016 yang memiliki nilai tertinggi adalah pelayanan kemampuan petugas dalam memberikan pelayanan dan pelayanan kesesuaian persyaratan pelayanan dengan jenis pelayanan masing-masing sebesar 85,42, sedangkan yang memiliki nilai terendah adalah pelayanan kewajaran biaya untuk mendapatkan pelayanan dan kesesuaian antara biaya yang dikeluarkan dengan biaya yang telah ditetapkan yang masing-masing nilainya sebesar 77,75.

\section{DAFTAR PUSTAKA}

Achmad Nurmandi. Manajemen Pelayanan Publik Lampiran UU No. 25 tahun 2009 tentang Pelayanan Publik. Jakatra: Sinergi Visi Utama, 2009.

Amri Marzali. Antropologi dan Kebijakan Publik. Jakarta: Kencana Prenada Media Group, 2012.

Deni Darmawan. Metode Penelitian Kuantitatif. Bandung: Remaja Rosdakarya, 2013.

Fandy Tjiptono. Manajemen Jasa, Edisi Pertama. Yogyakarta: Andi Offset, 2004.

Oka A Yoeti. Customer Service Cara Efektif Memuaskan Pelanggan. Jakarta: Prandya Paramita, 2003.

Rully Indrawan dan Poppy Yaniawati. Metode Penelitian Kuantitatif, Kualitatif, dan campuran untuk Manajemen. Pembangunan dan Pendidikan. Bandung: Refika Aditama, 2014.

Septiana Dwiputrianti dan Anwar Sanusi. Evaluasi Kebijakan dalam Upaya Peningkatan Mutu Human Capital di Sektor Publik (Comparative Study dengan Australia) dalam Pengembangan Human Capital, Perspektif Nsional, regional dan Global. Yogyakarta: Graha Ilmu, 2012.

Suharsimi Arikunto. Manajemen Penelitian. Jakarta: Rineka Cipta 2007.

Wisnalmawati, "Pengaruh Persepsi Dimensi Kualitas Layanan Terhadap Niat Pembelian Ulang", Jurnal Ekonomi \& Bisnis, Jilid 10, No. 03 (Juni: 2005).

Yanuar Ikbar. Metode Penelitian Sosial Kualitatif Panduan Membuat Tugas Akhir/Karya Ilmiah. Bandung: Refika Aditama, 2012. 